\title{
Advocacy of Competition in the Mechanism of State Regulation of the Economy
}

\author{
Olga Bakalinska ${ }^{1}$, Olena Belianevych ${ }^{1} \&$ Olena Honcharenko ${ }^{1}$ \\ ${ }^{1}$ Research Institute for Private Law and Entrepreneurship Named After Academician F. G. Burchak, Kyiv, Ukraine \\ Correspondence: Olga Bakalinska, Research Institute for Private Law and Entrepreneurship Named After \\ Academician F. G. Burchak, Kyiv, Ukraine.
}

Received: October 26, 2019

Accepted: November 22, $2019 \quad$ Online Published: December 5, 2019

doi:10.5430/ijfr.v11n1p425

URL: https://doi.org/10.5430/ijfr.v11n1p425

\begin{abstract}
The multifaceted competitive policy promotes awareness of the importance of competition by society, ensures maximum transparency of state regulation, reduces the level of corruption and increases public confidence within activities of the competition authorities, helps developing self-regulation of economic entities. At the same time the mechanism of state regulation and self-regulation has its own instruments for improving the efficiency of advocating competition. Research of their peculiarities, instruments, role and interaction are important directions of modern scientific investigations and the purpose of this article. In this article a comparative method to study is used for common and distinctive features of advocating of competition in different countries and Ukraine. The results show that it is extremely important to create a system for advocating of competition in order to inform society, protect the attained level of competition in entrepreneurial activity, prevent or suspend, and then stop the abuses of monopoly position, the anti-competitive concerted actions of business entities, the anti-competitive actions of state authorities and unfair competition. The experience of economically developed countries convincingly suggests that such practices have a positive effect on the functioning of the competitive environment in which the interaction of economic agents takes place. The results show that there was a gap in implementation of economic policy in Ukraine and there is a gap between legally established norms on the implementation of competition policy and the practice of their application. To a large extent, this is due to the lack of well-developed strategy for economic development in Ukraine and, accordingly, the strategy for the development of competition policy.
\end{abstract}

Keywords: advocacy, economic competition, competition policy, state regulation, self-regulation, the competition authorities

\section{Introduction}

Advocating of competition means organizing communication in order to promote principles of competition beingan addition to law application: on one hand, it is intensified by active advocacy and, on the other hand, advocacy is less effective in the absence of law enforcement. In modern conditions, the restriction by the use of compulsory state measures of competition policy on the part of the state is ineffective and expensive, and therefore needs to be complemented by self-regulation instruments that include the advocacy of competition. The problem of advocating of competition was studied by scientists mainly from the point of view of the state policy influence, using instruments of state regulation.

An important question remains: why the competition requires advocacy? In our opinion, the globalization process taking place in the world is the answer. Rapid technological changes, new alternatives appear to be challenges that require the same adequate response from society in order to ensure the stability of its development. Liberalization and convergence are grounds for strengthening the role of self-regulatory institutions, for the development of its internal structures, for changing the paradigm of interaction and cooperation with the state and, generally speaking, the transformation of statehood. Transformations, above all, acquire the regulatory and control functions of the state in relation to competition. Therefore, the issue of advocating of competition in the view of transformation and modernization of the state function is relevant.

Modern state regulation of the economy can be defined as follows: 1) direct state regulation; 2) the allocation or delegation of functions of the state to other entities; 3) creating conditions for establishment of self-regulation and co-regulation institutions. Therefore, when forming the culture of competition, the state pursues policy of creating 
conditions for institutional and conventional self-regulation. A positive feature of self-regulation is the awareness of the subjects of management for the importance and feasibility of competition and the implementation of advocating of competition policy at the local level. The state in its turn transforms the control and supervision function and therefore saves its own resources.

\section{Literature Review}

The issue of competition protection was studied by scientists mainly from the point of view of the influence of state policy and instruments of state regulation. G. Emberger points out that advocacy is one of the most important pillars relied upon of the competition agencies around the world when protecting effective competition (Emberger, 2006). Should recognize B. Begovic's conclusions, that competition is good for the economic growth of the SEE countries. Their growth is based on the increase in the total factor productivity, mainly on account of the restructuring process and reallocation of resources, but also due to the adoption of modern technology. The author substantiates that competition provides key incentives for this type of economic growth and no disadvantage of competition has been recorded for the total factor productivity based growth. Accordingly, effective competition policy in the SEE countries is essential for avoiding the middle income convergence trap (2018). S.J.Evenett concludes that competition advocacy represents a soft power in promoting competition and liberalization measures to improve the performance of market-based economies; keeping in mind the objective of "promoting a competitive environment for economic activities", replacing (or avoiding) regulations with more anti-competitive effects by government measures with less adverse effects, that seems to be one of the operational ways of interpreting this objective of competition advocacy (2006). There is widespread recognition that one of the most important contributions of a competition policy system is to serve as an advocate within the government and the country at large for reliance on market processes and business rivalry to organize the economy activity (Kovacic, 2001). The question of maintaining the competitive environment, the basic norms of the "framework" of the competitive environment in Ukraine is investigated by H. Lozova (2002; 2003); the scholar came to the conclusion that distorted reproduction of the basic norms of competition hinders the development of competitive relations in Ukrainian society. Also, the researchers studied the issue of the framework for the activities of the competition authorities. I. Rakic came to conclusion that the effectiveness of competition advocacy depends not only upon the strength and characteristics of the competition authority, but also on the framework within which it operates (2018).

However, the researchers studied the issue of the impact of self-regulatory instruments on the protection of competition. According to William E. Kovacic's observations, "Implementation is the Achilles' heel of competition law reform in transition economies. Foreign donors and transition economies tend to have minor implementation concerns in preparing new antitrust legislation. Successful implementation requires not only careful design of substantive prohibitions and the construction of an effective enforcement body, but also involves improvements in other institutions such as courts, professional associations and universities that influence the direction and impact of competition policy" (1997). Ukraine faces problems with the implementation of advocating competition policy.

At the same time, the issue of the influence of self-regulatory instruments on effective advocacy of competition, as well as their interaction with state mechanisms, is not sufficiently studied. However, it should be emphasized that the state policy of effective advocacy of competition should be based on a combination of state regulation instruments and the development of self-regulatory institutions, which ultimately leads to co-regulation. Involvement of state instruments and self-regulation into regulating advocacy of competition is a modern direction of transformation of social relationship. In addition, such co-regulation can serve as a factor in both globalization and the process of globalization in a particular country.

\section{Method}

The philosophical (dialectical) method was used to consider of advocate competition as an innovation tool in public administration, taking into account globalization trends. A comparative analysis of the advocacy ofcompetition in Ukraine and other countries has been made on the basis of descriptive characteristics. The formal-logical method was used in the work to determine the concept and content of advocating competition.The method of analysis and synthesis allowed to identify the objects and subjects, the role of advocating competition in the state mechanism. The systematically-functional method was used to find out the purpose of competition policy in the direction of advocating competition, to compare the instruments of state regulation and self-regulation in the advocacy of competition, the question of their interaction. On the basis of systematic approach, a generalization of the main tendencies of the advocacy of competition in Ukraine and the world took place. 


\section{Findings and Discussion}

\subsection{The Concept and Essence of Advocacy of Competition}

The basis for advocating competition is the definition formed by the advocacy working group of the International Competition Network and is defined as "one of the activities of antitrust authorities, aimed at strengthening the competitive environment through mechanisms that do not involve the use of coercive measures, and use of active relationships with other government agencies and an increased understanding by the general public of the benefits of competition" (Advocacy and competition policy, 2002; Murrisa, 2002).

By defining public interests for advocacy, we find evidence that advocacy in general case is a phenomenon that is different from lobbying (Darity, 2008). We find similar position in defining such a concept as advocacy of politics (Tertichka et al., 2014).

Advocacy of competition is any activity carried out by competition authority to promote values of the market environment by the way of non-compulsory means (A decade of ICN activity, 2011). Todd J. Zywicki and James C. Cooper add that broadly, competition advocacy is using persuasion, rather than coercion, to convince government actors to pursue policies that further competition and consumer choice (Zywicki et al., 2007).

Competition policy is a long-running work in progress, and the development of well-conceived initiatives today requires careful, accurate view of what happened in the past and a commitment to learn why specific measures (Kovacic, 2003). This idea is supported by William E. Kovacic: "Successful implementation requires not only the careful design of substantive prohibitions and the construction of an effective enforcement body, but also involves improvements in other institutions such as courts, professional associations and universities that influence the direction and impact of competition policy" (1997). Competition policy is embedded in a wider and more interconnected system of institutions and policies, which could present an intrinsic complementarity (Aghion and Howitt, 2006). With the help of state regulation of the economy the limits of interference with self-regulation are determined. Negative effects of spontaneous market relations as well as spontaneous self-regulation can be overcome with the limits established by the state for own discretion and permissible conduct of business entities. Independent self-regulation should be the object of legislative influence (mainly in the form of imperative norms) to the extent that it requires protection of public interests in the field of management in general and on several markets (Belianevych, 2016).

As we see, scholars emphasize on the systematic and inseparable advocating competition from other state institutions. Obviously, advocating competition is part of the state's policy. Therefore, the advocacy of competition must be embedded into the state mechanism that is to be its harmonious element, but not a destructive annex.

The competition advocacy model, which emphasizes the regime's influence, develops narrower political alternatives, supports the liberalization process without prejudice to any increase in efficiency (Rodrigeuz et al., 1997). According to T.Zywicki and others "... competition advocacy helps to solve the consumers' collective action problem by acting within the political system to advocate for regulations that do not restrict competition unless there is a compelling consumer protection reasoning for imposing such costs on citizens (Zywicki et al., 2005). Therefore, a quite logical element for effective advocacy of competition is the use of self-regulatory instruments: self-regulatory organizations (institutional component), virtue practices, compliances. The essence of self-regulation is the potential and real possibility for subjects to create their own behavior and act without any external influence (Goncharenko and Neskorodzhena 2018). Protection of consumer rights like a certain imperative serve as a kind of restriction to advocating competition. Thus, advocating competition and using self-regulating mechanisms for this in the form of self-regulatory organizations is a positive and relevant instrument. However, balancing and restrictions should be established then. Moreover, such restrictions are quite flexible and proceed primarily from the competitive policy of the state.

The effectiveness of the state self-regulation is supported and approved by the relevant state basis: first of all, the regulatory framework is improved in order not only to create truly functioning self-regulation mechanisms, but also to prevent unfair competition between self-regulatory subjects themselves; secondly, the support of the relevant organizational structures of self-regulation (associations, chambers of commerce and industry) as representative structures operating in the relevant spheres with the possible delegation of certain powers (Goncharenko, 2018).

Advocacy is mainly directed on the subjects of power, those who make decisions and are responsible for the policy in a particular field or sphere. The result of advocacy becomes a change in policies, laws, decisions and practices that improve certain indicators, conditions and markets, depending on the area in which it is applied along with taking into account the interests of the groups for which it is going on. At the same time, the advocacy of competition 
promotes communication between public authorities and market structures, as well as the development of a competitive environment. This is mainly the development of interaction with other authorities, as well as raising the awareness of the general public about the benefits of competition.

Consequently, advocating competition in practice complements the function of anti-monopoly coercion in the implementation of competition policy. Indeed, because of ignorance and misunderstanding assignments of competition policy in society it is often possible to find expression that anti-monopoly authority in the country is not needed or required only for populist purposes. Advocating competition, first of all, supports the law enforcement system by informing market participants about the content of the rules, which increases their readiness to use competition law to protect their rights. It extends awareness of potential violators not only about legal actions, but also about the efforts the anti-monopoly authority is to commit to detect violations and punishment of the offender, which increases the subjective assessment of the probability of punishment when choosing between actions "to violate the law "and" restrain from violating the law". It also reduces the possibility of creating and applying standards that contradict the spirit of competition policy by government authorities.

Today in the development of advocacy of competition, one can distinguish the following main trends: strengthening the activity of national anti-monopoly (competition) agencies in advocacy of competition; spread of international cooperation in the field of advocacy of competition (through the creation of international formal and informal governmental organizations); awareness of developing countries and post-transformational economies in necessity to complement coercive instruments by advocating competition, gradually integrating them into advocacy of competition; updating practical tools for advocating competition, focusing on case studies, investigating specific situations, like competitive agencies such as members of the International Competition Network (ICN) conduct their activity on advocating competition in practice (Advocacy Toolkit, 2011); conducting assessment of effectiveness of the competition authorities' activity in advocating competition; exchange experience on advocating competition between countries through conferences, tele-seminars, publication of information and articles in mass media, in particular, on websites; the development of a competitive culture within society and the encouragement of competition authorities to spread a competitive culture (ICN Advocacy Working Group); penetration of the principles of competition into government political decisions; carrying out activity by international organizations and national competition authorities to explain the benefits of competition to different target groups; recognition of the key role of competition as the driving force of economic growth and innovation (The ICN Advocacy Working Group); taking into account the influence on competition of interference of anti-monopoly (competition) agencies on the functioning of markets; the priority of socially significant issues of advocating competition, which have a significant cumulative effect on the economy in the whole, such as transport, energy, financial market; development of self-regulatory tools (compliance, voluntary agreements, virtue practices, etc.).

\subsection{Objects and Subjects of Advocacy of Competition}

World practice in objects of advocacy of competition includes business entities (business environment). If national entities avoid a breach of competition law, they will fully possess the rules of fair competition within the country, which is be a guarantee for their competitiveness not only on the national market, but also when entering the international market; all branches of power (legislative, executive and local government bodies; courts). Competitive policy is not limited to frames of competitive laws. It is necessary that other normative acts adopted by the authorities contribute to the development of a competitive environment in the country. Analysis of the regulatory legal acts of the authorities regarding their compliance with anti-monopoly/competition legislation is to help to detect illegal acts and decisions at an early stage, and to prevent their adoption.

Advocacy of competition is also aimed at improving the acknowledgement of national judges in the field of competition law (first of all, regarding the ability to differentiate between the legal and the illegal from the point of view of anti-monopoly legislation actions), their awareness of benefits of competition; professional associations; the media and the public. They should receive information on important events in the field of competition. Publications in the media may be the reason for initiating anti-monopoly investigations. The public should know where to apply as for the monopolists in the case of violation of legal rights by officials or companies. Advocating competition fosters public education, enlightenment and, ultimately, general economic development; academic circles (scholars, teachers, students, primarily of legal and economic specialties). Necessary are the researches related to competition issues during the financial and economic crisis, regulating and strengthening free fair and open market relations; consumers. Awareness of the benefits of competition will probably help to improve the quality of living standards. The consumer is going to have an opportunity to choose quality product that meets his needs in the required quantity and at an affordable price. 
Consequently, the advocacy of competition is aimed, first of all, at the following target groups: business audience and public (consumers). A key factor in the modern business world is building relationships. Social networks in this aspect are becoming more and more attractive for the formation of a competitive culture in society. The main organized and active subject of advocating competition at the macro level is the national competition authority (anti-monopoly) of the country. In some cases, the subject of advocacy of competition may be expert sector councils, expert communities. In Ukraine the Anti-monopoly Committee of Ukraine is exclusively engaged in advocating competition.

At the international level, international competition law enforcement bodies are international legal institutions: international conferences, congresses, forums and meetings, international committees and commissions, international organizations with which the AMCU collaborates, in particular with the OECD Competition Committee, the European Commission, International Competition Network (ICN), UNCTAD, etc.

The existence of independent regulators is important for the advocacy. In particular, they should be more sympathetic to competition authorities in their efforts to promote competition (Gesner et al., 2005). The main organized and active subject of advocacy of competition is the anti-monopoly (competitional) agency of the country -State executive body, which ensures the implementation of competition policy. For example, in Ukraine it is the Anti-monopoly Committee, in Moldova - the National Agency for the Protection of Competition, in Kazakhstan the Agency of the Republic of Kazakhstan for the Protection of Competition (Anti-monopoly Agency), in Austria the Federal Competition Authority, in the UK - the Competition Commission, in Italy - the Competition Authority, in Canada - the Canadian Competition Bureau, in the United States - the Federal Trade Commission Competition Bureau, etc. Competition agencies may find appropriate advocacy opportunities in many ways. For example, competition agencies can identify relevant competition advocacy issues on their own initiative, using techniques such as 'horizon scanning'33 (Horizon scanning is a technique for detecting early signs of potentially important developments through systematic examination of potential threats and opportunities) (Guidelines for implementing competition).

According to James C. Cooper, Paul A. Pautler and others: "competition advocacy then concerns both existing state intervention and possible future interventions. ... the competition authority acts on behalf of those other groups in society for whom the organizational costs are too large or the costs of informing themselves so high that they offer effective opposition to the proposals that will favor the proponents' economic interests at the expense of the competition process (Zywicki et al., 2005). It is important to study the function of a competitive body based on systematic analysis of the whole state policy and legal system of a particular state.

\subsection{Ukraine Experience on the Competition Advocacy}

Ukraine is a post-transformational economy country. Competition is a special area of relations that requires state support and adjustment not only in the form of anti-monopoly policy, but also the purposeful advocacy of competition in society. The fact is at the informal level in the consciousness of Ukrainian society the norms in tangled into conflict with the new formal institutes have become firmly established. A striking example of the contradiction is the conflict between the formal rules of the protection of economic competition, filed into the competition legislation of Ukraine, and the existing sub-institution of corruption in the country, which allows even inefficiently operating companies to beat their competitors by gaining unfair competitive advantages or creating a variety of administrative barriers for competitors (Bakalinskaya, 2014).

Ukraine has established the legal framework for advocating competition. The Constitution of Ukraine guarantees state protection of competition in Ukraine (Constitution of Ukraine, 1996). The Economic Code of Ukraine establishes the provisions of antitrust and competition policy of the state (Economic Code of Ukraine, 2003). Ukraine adopted the Law "On the Antimonopoly Committee of Ukraine" dated 26.11.1993 No. 3659-XII, Law "On the Protection of Economic Competition" dated 11.01.2001 No. 2210-III (this law defines the legal basis for the support and protection of economic competition, the restriction of monopoly in economic activity and is aimed at ensuring the effective functioning of the Ukrainian economy on the basis of the development of competitive relations) (Law of Ukraine, 2001), Law "On Protection from Unfair Competition" dated 07.06.1996 No. 236/96-BP (this law defines the legal framework for the protection of business entities and consumers against unfair competition) (Law of Ukraine, 1996).

The Antimonopoly Committee of Ukraine is a state body with a special status whose purpose is to provide state protection of competition in entrepreneurial activity and in the field of public procurement (Law of Ukraine, 1993). However, there are no adequate institutional mechanisms to ensure the synthesis and analysis of available information in the Antimonopoly Committee of Ukraine. Active cooperation with the public, ensuring the principle 
of transparency in work and the formation of pro-competitive consciousness in society is a priority area of activity of the Antimonopoly Committee of Ukraine. The Committee supports the study of public opinion to take it into account when formulating and implementing public policy.

The Antimonopoly Committee of Ukraine conducts various events with the participation of representatives of public circles: conferences, seminars and round tables. Also, the Committee constantly cooperates with mass media, publishes data on its activities, all open socially important decisions, legal acts, etc. The Committee monitors the situation in commodity markets that have a significant impact on the socio-economic situation in the country, in particular, in the markets for bread and bakery products, oil products markets, and so on. In order to prevent violations of the legislation on the protection of economic competition, the Antimonopoly Committee of Ukraine widely uses such a tool as providing recommendations to market participants. In our opinion, the effectiveness of advocating competition within the business community largely depends on the regularity and complexity of the activities.

Analysis of the situation in Ukraine with regard to the activity of private individuals and firms in protecting their rights rose as a result of monopoly and unfair competition, and shows that competitors are predominantly the plaintiffs. Also, there are no sufficiently developed self-regulatory instruments, which lead to ineffective advocacy of competition. The opinion of T.Calnescu, G.Likhonosova and O.Zelenko on today's transformation of socio-economic situation and real indexes of macro- and microeconomic state of Ukraine lead to the immedi at enecessity on activation of the national consciousness, the development and introduction on mechanisms of acceptance on adequate decisions, increase of social and economic activity, social mobilization and own national economic positioning (Calnescu et al., 2018).

In our opinion, the viability of market competitive environment in Ukraine is the higher, the deeper its integration within social policy, that is the more people consider competition as condition of their own economic security. The main goal of advocating competition in Ukraine is to create an effective system of participants informational market about the possibilities of using legislation on the protection of economic competition to secure their rights, establishing legitimate enforcement in this sphere, expanding the range of objects in competition policy, involving market participants into the implementation of anti-monopoly measures, stirring up interest of scientific and educational circles to research in the field of competition.

Among the main challenges of advocating competition in Ukraine there are the following that can be singled out: increasing awareness of the importance of competition and the adoption of competition principles in Ukrainian society; introduction of norms and rules of competition into the activity of state authorities, courts, business structures; development of competition on national and regional markets; reduction of the number of anti-monopoly laws violations business entities in the commodity and financial markets; reducing the number of violations of anti-monopoly laws by public administration and self-government bodies; reduction of the number of violations of anti-monopoly laws by entities of natural monopolies; lowering unfair competition; preventing and stopping anti-competitive actions of market participants through raising their awareness; involving general public in discussing the issues of competition development and working over competitive environment in the country; consideration of the results of public discussions in the activity of the antimonopoly body; development of self-regulating mechanisms.

The main task of the Antimonopoly Committee of Ukraine when working with such a target group as the public is to report to each member of society that awareness of the benefits of competition, compliance with the norms of competition law will enhance the quality of life. Consumers will be able to choose the best quality product that best suits their needs, in the required quantity and at an affordable price. The best channels for working with this audience are the organization of publications through the media and the Internet. Publications in the media may be the reason for initiating antitrust investigations. The public must know where to turn in the event of a breach of legitimate competition rights on the part of officials or unscrupulous companies. Advocating competition contributes to raising public awareness, forming a competitive culture and, ultimately, general economic development.

The strategy of advocating competition, the choice of methods, tools for various objects of advocacy of competition depends on the level of awareness of the target audience in the field of competition policy. The strategy should also take into account the ability of certain stakeholders to self-organize to protect their rights (in particular, in antimonopoly lawsuits) and the possibility of lobbying their interests in the development of competition law.

A Public Council was created in Ukraine under the Antimonopoly Committee of Ukraine at constituent meetings with the participation of civil society institutions. The Public Council of the Antimonopoly Committee of Ukraine is a permanent collegial electoral consultative and advisory body formed by the Antimonopoly Committee of Ukraine 
to ensure the participation of citizens in the management of state affairs, the exercise of public control over the activities of the Committee, the establishment of effective interaction of the Committee with the public, the consideration of public opinion during the formation and implementation of state policy. The Public Council acts on a voluntary basis. The purpose of the creation of the Public Council is to coordinate activities related to conducting public consultations on the issues of formulation and implementation of state policy in the field of protection of economic competition, in order to take into account public opinion in the process of preparation, adoption and implementation of the Committee's decisions (Charter on the Public Council under the Antimonopoly Committee of Ukraine, 2011).

Advocacy of competition should be aimed at solving the following tasks: influence on the lawmaking process in order to protect competition; clarification of provisions of the laws through the development of relevant regulations and comments; establishment of a constructive dialogue between antimonopoly bodies and state, and local authorities responsible for the formation and implementation of regulatory policy in order to minimize the restrictive effects on competition; measures to regulate the activities of economic operators of the market being developed or used; raising awareness among all sectors of society of the importance of competition and the possible losses of the consumers and the economy in the whole as a result of its constraints; informing domestic and foreign companies about existing rules for regulating competitive relations on the market in order to forecast economic activity and increase the attractiveness of the Ukrainian economy; an educational campaign, explanation of the rules of anti-monopoly law, ensuring the availability of information on the restrictions contained and requirements that impose anti-monopoly legislation on economic entities in different cases; ensuring cooperation of the company with the anti-monopoly authorities in order to identify violations of the antitrust laws and collecting necessary information; ensuring the understanding of the nature of competition by society, the importance of implementing anti-monopoly laws and strong competitive policy.

\section{Conclusion}

Advocacy of competition is a system of anti-monopoly bodies activity aimed at strengthening the competitive environment and clarifying the positive role of competition in society through non-coercive methods, mainly through the interaction of competitive agency with other public and private subjects and increasing public awareness as for advantages of competition. While advocating competition in developed countries is one of the main branches of competition policy, in Ukraine such activities are relatively new and therefore require careful study, research and development of recommendations based on the synthesis of the best world experience in this field.

Advocacy of competition is aimed, first of all, at the following target groups: business audience of the public (consumers). A key factor in modern business world is the building of relationships. Social networks in this aspect are becoming more and more attractive for the formation of a competitive culture in society. Effective implementation of measures to advocate competition is possible along with the establishment of appropriate organizational and institutional prerequisites only.

At the present day in the context of the development of globalization and integration processes, advocacy of competition should be considered as a component of national competition policy and as a prerequisite for the development of international competition and free international trade.

Ukraine has certain features regarding the advocacy of competition and the competence of its competitive agency the Anti-monopoly Committee. Unlike the European Union countries, where the initiators of advocating competition were business entities, in Ukraine, as a post-Soviet state, the leading entity of this process was the Anti-monopoly Committee. The system of institutional self-regulation in Ukraine is still rather weak, therefore the implementation of the functions of advocating competition without a state mechanism is not to be possible. At the same time, Ukraine is trying to create an effective mechanism for advocating competition by implementing policy of decentralization and deregulation, including self-regulation mechanism.

Advocating competition is often viewed through the prism of state policy and state regulation. However, the current trends in the transformation of society, the study of their globalization trends, including processes in the international economy, leads to the idea that without self-regulation mechanisms successful advocacy of competition is impossible to imagine and its effectiveness is questionable. Self-regulation of advocacy of competition should be considered as an adequate and actual answer to the rapid development of competitive relations. It is implemented in those cases when there is no timely reaction of the state to the changes that take place or it is necessary to apply other approaches different from those of direct government instruments.

Hence, effective economic policy, first of all, is to be aimed at establishing an institutional system, within which the 
competitive mechanisms, in particular, self-regulatory mechanisms can function normally. The established institutional structure cannot be considered once and for all, changes in competitive relationships require appropriate changes in the institutional structure, which needs to be adjusted in accordance with the demands emerged. Of course, the control over this process is put onto the state, since even the best laws regulating competitive relations do not insure against the false development of events in the future due to the presence of inertia and resistance from the side of old organizations onto the new ones, and against the action of the cumulative effect too. The main problem in formation of the competitive environment is the establishment and constant modification of such conditions that would protect market participants from abuse of market power, and on the other hand, from invasion of political or private forces, strengthening of state power, etc.

\section{References}

Advocacy and competition policy. (2002). Report prepared by the advocacy Working Group. ICN's. Conference, Naples, Italy. Retrieved from http://www.internationalcompetitionnetwork.org/uploads/library/doc358.pdf

Advocacy Toolkit. Part I: Advocacy process and tools. (2011, May). Prepared by ICN Advocacy Working Group. Presented at the 10th Annual Conference of the ICN, The Hague. Retrieved from http://www.internationalcompetitionnetwork.org/uploads/ library/doc745.pdf

Aghion, P., \& Howitt, P. (2006). Appropriate Growth Policy, Schumpeter Lecture: A unifying framework. Journal of the European Economic Association, 4(2-3), 269-314. https://doi.org/10.1162/jeea.2006.4.2-3.269

Bakalinskaya, O. O. (2014). Legal regulation of fair competition in Ukraine. Kyiv: Research Institute of Private Law and Entrepreneurship named after Academician F. G. Burchak NPRrN of Ukraine.

Begović, B. (2018). Middle income convergence trap and the role of competition policy in SEE countries (pp.43-61). https://doi.org/10.1007/978-3-319-76644-7_3

Belyanevich, O. A. (2016). The issue of self-regulation of economic activity. The stability of civilian turnover in Ukraine: problems of provision. In O. A. Belyanevich (Ed.), Collection of scientific works (Issue 4, pp. 18-35). Kyiv: SRI of Private Law and Entrepreneurship of the NAPR of Ukraine.

Calinescu, T., Likhonosova, G., \& Zelenko, O. (2018). Estimation of Conditions for Realization of Democratic Mechanisms in the Transformation of Society: Tearing Away and Social Dialog. Montenegro Journal of Economics, 14(1), 93-107. https://doi.org/10.14254/1800-5845/2018.14-1.7

Charter the Public Council under the Antimonopoly Committee of Ukraine. (2011, April 13). No 177. Retrieved from http://www.amc.gov.ua/amku/control/main/uk/publish/article/103928

Constitution of Ukraine. (1996, June 28). No. 254k/96-VR. Retrieved from https://zakon.rada.gov.ua/laws/show/254\%D0\%BA/96-\%D0\%B2\%D1\%80

Darity, W. A. (Ed.) (2008). International Encyclopedia of the Social Sciences (2nd ed., Vol. 6), USA, Macmillan Reference.

Economic Code of Ukraine. (2003, January 16). Retrieved from https://zakon.rada.gov.ua/laws/show/436-15

Emberger, G. (2006). How to strengthen competition advocacy through competition screening: Opinions and comments. Retrieved from http://ec.europa.eu/competition/publications/cpn/2006_1_28.pdf

Evenett, S. J. (2006). Competition advocacy: time for a rethink. Northwest JInt Law Bus, 26, 495-514.

Gesner, O. E., Lucas, L. M., Novaes, C. M., \& Ferreira, B. G. (2005, May). Aspects of the Independence of Regulatory Agencies and Competition. São Paulo. Retrieved from http://www.icn.de/NGA_Submission_Aspects_of_Independence.pdf

Goncharenko, O. (2018). State regulation and self-regulation of economic activity: the search for a balance. Entrepreneurship, Economy and Law, 3, 40-45.

Goncharenko, O., \& Neskorodzhena, L. (2018). Self-regulation of culture: the role of public associations and electronic communication. Herald of National Academy of Managerial Staff of Culture and Arts, 4, 121-125. https://doi.org/10.32461/2226-3209.4.2018.153002

ICN. (n.d.). ICN Advocacy Working Group: Long-Term Strategic Plan 2011-2016.

Kovacic, W. E. (1997). Getting Started: Creating New Competition Policy Institutions in Transition Economies. Brooklyn Journal of International Law, 23(2), 402-453. 
Kovacic, W. E. (2001). Institutional Foundations for Economic Legal Reform in Transition Economies: The Case of Competition Policy and Antitrust Enforcement. Chicago-Kent Law Review, 77(265), 265-315.

Kovacic, W. E. (2003). The Modern Evolution of U.S. competition policy enforcement Norms. Antitrust Law Journal, 71(2), 377-478.

Lauwers, I., \& Hooper, D. (2011, August). A decade of ICN activity: overview of the main achievements. EU Competition \& Regulatory. Legal and policy developments at the EU level. Retrieved from http://www.slaughterandmay.com/media/1591488/eu-competition-and-regulatory-newsletter-19-aug-25-aug-20 11.pdf

Law of Ukraine on Protection from Unfair Competition. (1996, June 7). No. 236/96-VR. Retrieved from https://zakon.rada.gov.ua/laws/show/236/96-\%D0\%B2\%D1\%80

Law of Ukraine on the Protection of Economic Competition. (2001, January 11). No. 2210-III. Retrieved from https://zakon.rada.gov.ua/laws/show/2210-14

Law of Ukraine On the Antimonopoly Committee of Ukraine. (1997, October 7). No. 554/97-VR. Retrieved from https://zakon.rada.gov.ua/laws/show/3659-12

Lozova, H. M. (2002). Institutional aspects of creating an effective competitive environment in Ukraine. Entrepreneurship, Economy and Law, 5, 117-121.

Lozova, H. M. (2003). Formation of a competitive environment in a transitive economy. Thesis Doctorate, Kyiv. Ukraine.

Murrisa, T. (2002). Materials of the First international competition network. Naples, Italy.

Rakić, I. (2018). The Role of Competition Advocacy: The Serbian Experience. Competition Authorities in South Eastern Europe. https://doi.org/10.1007/978-3-319-76644-7_7

Rodrigeuz, A. E., \& Malcom, B. C. (1997). Competition Policy in Transition Economies: The Role of Competition Advocacy. Brooklyn Journal of International Law, 23, 365-401.

Spfia Comepititaion Forum. (n.d.). Guidelines for implementing competition advocacy. United Nations Conference on Trade and Development. from https://unctad.org/meetings/en/Contribution/ccpb_SCF_AdvocacyGuidelines_en.pdf

Tertychka, V., Kobets', R., Nazaruk, V., et al. (2014). Policy analysis for advocacy campaign: guidelines. Kyiv.

The ICN Advocacy Working Group Work Plan for 2011-2012. (n.d.). Retrieved from http://www.internationalcompetitionnetwork.org/uploads/library/doc759.pdf

Zywicki, T. J., \& Cooper, J. C. (2007). The U.S. Federal Trade Commission and Competition Advocacy: Lessons for Latin American Competition Policy. George Mason University Law Economics Research Paper Series. Latin American Antitrust Developments.

Zywicki, T. J., Cooper, J. C., \& Pautler, P. A. (2005).Theory and Practice of Competition Advocacy at the FTC. Antitrust Law Journal, 72(3), 1091-1112. 